\title{
METHOD OF DETERMINATION OF THE DIURNAL ENERGY CONSUMPTION OF THE CADETS FROM THE VASIL LEVSKI NATIONAL MILITARY UNIVERSITY
}

\author{
Pavlin Glushkov ${ }^{1}$, Simeon Simeonov ${ }^{2}$, Marin Georgiev ${ }^{3}$ \\ ${ }^{1}$ Ph.D. National Military University, Veliko Tarnovo, Bulgaria, pavlin_glushkov@mail.bg \\ ${ }^{2}$ Ph.D. Student, National Military University, Veliko Tarnovo, Bulgaria, sansiood@abv.bg \\ ${ }^{3}$ Ph.D. National Military University, Veliko Tarnovo, Bulgaria, clementon@abv.bg
}

\begin{abstract}
The basic results and the used in the research methodology for determination of the diurnal energy consumption of the Cadets from the Vasil Levski National Military University are represented in the report. The methods for measuring the time expenditures and for determination of the most suitable method for the specified conditions were examined. The duration of the specific events in the time distribution of the 24hours period was analyzed and the physical activity ratio (PAR) for each kind of physical activity was determined - establishment of working time. Resulting form the carried out chronometry, at the end of the report the obtained results are being visualized.
\end{abstract}

Keywords: diurnal, consumption, cadets, rational nutrition.

\section{INTRODUCTION}

The question of the daily energy consumption, of the energy value of the nutrition and consequently the energy balance is of a special importance for the army. The knowledge of the physical load, connected with the training of the soldiers, the sort of the military unit and the specificity of the military service at the particular military unit ought to be a substantial element by the nutrition planning. On its part, it's appropriate that the food intake should cover the needed energy and to ensure all the necessary nutrition substances to the body in proper quantities and proportions.

\section{METHOD OF DETERMINATION OF THE DIURNAL ENERGY CONSUMPTION OF THE CADETS FROM THE VASIL LEVSKI NATIONAL MILITARY UNIVERSITY}

Methods for evaluation of the daily energy consumption (Nichev, 2017a, pp. 399-404; Terziev, Nichev, 2017b, pp. 627-630; Terziev, Nichev, 2017c, pp. 846-850; Terziev, Nichev, 2017d, pp. 631-635; Terziev, Nichev, 2017e, pp. 667-671; Human energy requirements, 2001a; Vaz, Karaolis, Draper, Shetty, 2005a)

Each vital, labor or household activity of the person is connected with energy consumption, which is formed in the organism in result of physiological processes of the incoming food. Oxygen is used during this 
process, while carbon dioxide, nitrogen compounds are released and warmth is liberated. The researchers divide the methods of evaluation of the daily energy consumption into two major groups: laboratory and estimated methods.

To the laboratory methods belong the versatile methods of the calorimetry - the method of the direct thermal calorimetry, based on the exact measuring of the liberated by the body warmth and the method of the respiratory energometry, based on the consumption of oxygen and the exhaled carbon dioxide. The liberated carbon dioxide can be measured using the method of the Reverse Fick. The method of the Reverse Fick is based on the measuring of the heart capacity (warmth dilution) and the difference of the oxygen concentration between the arterial and the mixed venous blood. The Method of the Nutrition Energometry is based on the laboratory analysis of the nutrition value of the taken food and the unassimilated part of the food or upon the evaluation of the energy value of the taken food and weight control during a specified time period. By the method of pulse measuring, with the help of a special appliance - pulse tachometer, the frequency of the pulse is measured during the performance of different physical activities and the results are transformed into kilocalories.

The estimated methods are based on the ground metabolism and factors of physical activity. In these methods the ground metabolism is determined separately with the help of formulas, based on the factors, sex, weight, age and height. The sum of the values obtained shows the amount of the consumption for the ground metabolism.

In 2001 the Food and Agriculture Organisation (FAO) of the United Nations Organisation published a Report on behalf of the Food and Agriculture Organisation (FAO), of the World Health Organisation and the University of the United Nations (UNU), where a wide range of experts evaluate the level of the scientific knowledge for determination of energy needs of the population and suggest recommendations for the nutrition of the population. It's established in the report, that the evaluations mustn't be based solely on physical efforts in result of professional work, because there are people with professions with less physical load, who exercise active physical activity during their free time, and people with big work loads, who have sedentary way of life during the rest part of the day. On that basis the diurnal energy consumption is determined by the way of life, which combines the obligatory physical works and the physical activity during the free time. The researches of the WHO demonstrate that the average energy consumption during the 24hours period must be the same both for men and for women.

The table-chronometric method reads exactly the spent time for a specific activity. The obtained data, with the help of tables of the energy consumption for different kinds of activities allow us to determine the daily energy consumption of the person. Initially the time consumption is measured separately for the daily activities of a particular person, fixing their duration.

The analysis of the methods of evaluation of the daily energy consumption brings the conclusion, that the most suitable method for determination of the daily energy consumption of the Cadets from the Vasil Levski National Military University is the method, proposed by the Food and Agriculture Organisation, the World Health Organisation and the UN University, which needs to be adapted to the specificity of the activity of the Military University.

\section{Research of the duration of the events, included in the time distribution}

According to the „Rules for the internal discipline of Vasil Levski National Military University, announced by Order Nr. 529 from April, $12^{\text {th }}$ 2012, the basic events, included in the time distribution, are: universal actions; actions, connected with the training process; specific actions; additional actions. The universal actions regulate the working time and the weekend rest of the commanding and the teaching staff, of the instructors and the support staff at the Vasil Levski National Military University.

The actions, connected with the training process, comprise: the school hours; the hours for self-training; the periods for amendment of bad current marks; the time for tutorials and classes instructions; weekly organization of the educative process; analysis of the educative process; sessions of the Rector, Dean and College Councils.

The specific events are connected with the preparation of the Cadets for the performance of the military service as profession and comprise: getting up in the morning; physical exercises, including morning exercises and sporting-mass work; individual dressing; cleaning of the bedrooms and areas; feeding time; time for falling in and trainings; private time; retreat time; time for sleep (8 hours). According to the characteristic of the activity within the specific events, working time and private time can be distinguished.

The additional actions determine the times for: preparation and instructing and doing the service of the 24hours fatigue; cleaning and servicing of the weapon. 
The events, connected with the education process and the specific events are of big interest for the needs of the present research. Both of them are entirely covered by the definition "educative process". A big number of researchers had analyzed the educative process from different points of view, but an overall study of the 24-hours' time requirement is missing from the scientific literature. The examination of the 24-hours' time requirement for the educative process at Vasil Levski National Military University is a basic starting point for the analysis of the educative time and for the elaboration of other kinds of time standards.

Out of the point of view of the analysis of the 24-hours' time distribution at "Vasil Levski National Military University" practically two basic groups of methods for study of the 24-hours' time requirement for the educative process can be used, and namely: methods of direct study of the time requirements and methods of indirect study of the time requirements.

The methods of direct study of the time requirements can be divided into: methods for examination of a part of a specified action or of an element of a particular educative function and methods for examination of the aggregate time requirements.

The specific of the educative process at Vasil Levski National Military University presumes a large extent of detailing and regulation of the daily actions. A significant part of the actions, grounded in the time distribution, are regulated by the Regulations of the Military Service, by the rules of the University, by the orders of the Superior of Vasil Levski National Military University or there exist ratified instructions, methodologies and further documents, possessing an obligatory nature. This presumes their separation into elements of the specified educative function, which can be studied independently from each other.

The carried out examination of the methods for study of the time requirements and of the specificity of the educative process bring the conclusion, that the most suitable method to apply when studying the 24-hours time requirements, is the method of chronometry.

The chronometry is one of the main methods for examination of the time requirements, which is used in practice for the research of the duration of the most momentary elements of the particular activities.

The essence of the chronometry as a method for research of the time requirements is reduced to specifying, writing down and processing of their duration in respect of determination of their objectively needed extent in specified conditions. Depending on that, whether the object of chronometry are the brief and the frequently most repeated elements of the operation, work or function, performed by a single person or many persons, we distinguish individual and group chronometry.

\section{Research of the basic actions, included into the time distribution during the 24-hours period}

The research of the basic actions, included into the time distribution during the 24-hours period was carried out during the period 25-26th of April, 2017. In result of the analysis a chronogram of the organization and of the structure of the 24-hour day of the Cadet at Vasil Levski National Military University - Region Veliko Tarnovo, was elaborated, according to the time distribution. The time distribution during the 24-hours period, according to the characteristic of the activities is shown on figure 1.

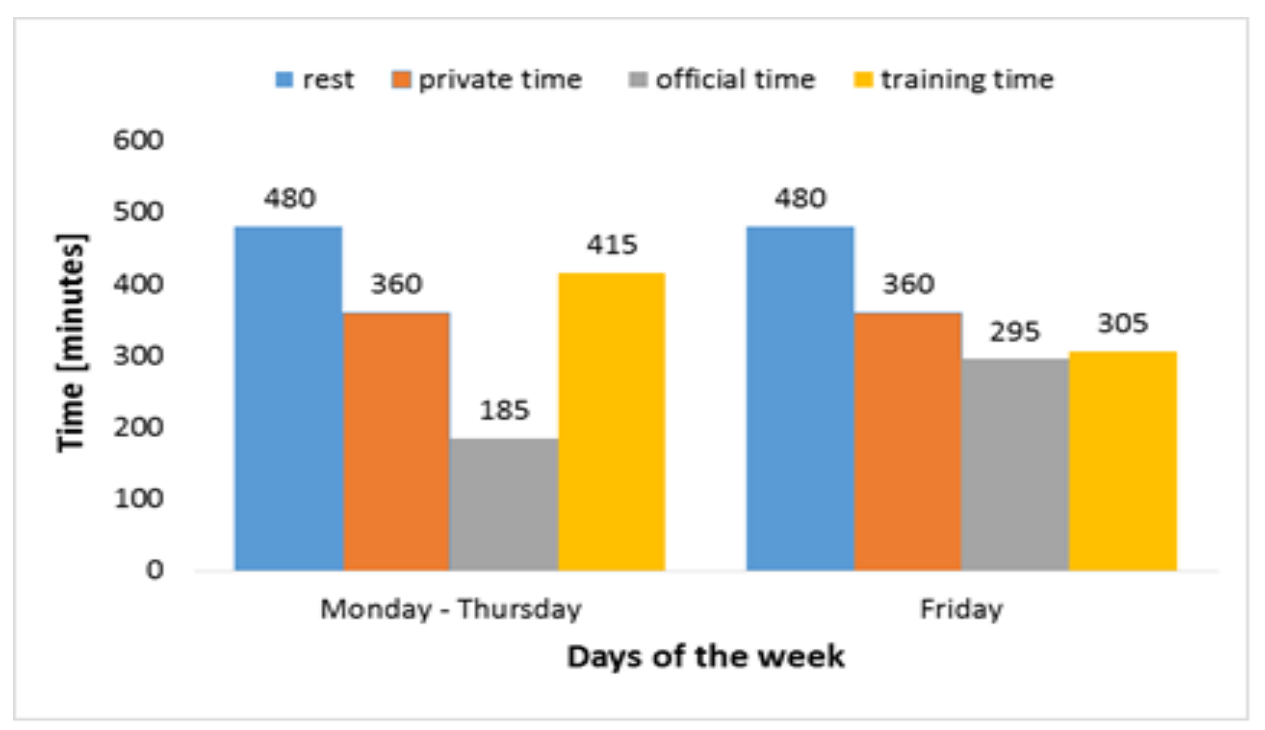

Fig. 1: Distribution of activities during a 24-hours period. 
It's obvious, that the time, spent for rest (sleep) and the private time occupy $58.3 \%$, the training time on the days from Monday to Thursday cover $28.8 \%$ and on Friday $21.2 \%$, while the official time occupies respectively $12.9 \%$ and $20.5 \%$ of the 24 -hours period.

\section{Analysis and determination of the physical activity standard for the official time}

During the period 02.05.2017 - 12.05.2017 a group chronometry of the duration of specific events, having the property of an official activity, of the time distribution during the 24-hours period at Vasil Levski National Military University was carried out. The group chronometry was performed with the help of the method for current observation and comprised cadets, studying in the Faculty "General Forces". The results of the implemented chronometry are generalized in Table 1.

Table 1: Generalized data from the chronometry of the time distribution during the period 02.05.2017 $-12.05 .2017$

\begin{tabular}{|c|c|c|c|}
\hline № & Type of activity & $\begin{array}{l}\text { Average } \\
\text { value } \\
\text { (in min) }\end{array}$ & $\begin{array}{l}\text { Deviation from } \\
\text { average value } \\
\text { (in min } \pm \text { ) }\end{array}$ \\
\hline \multirow[t]{4}{*}{1} & Breakfast & & \\
\hline & Standing & 20 & \pm 2 \\
\hline & Eating & 18 & \pm 1 \\
\hline & March & 2 & +1 \\
\hline \multirow[t]{3}{*}{2} & Preparing for classes and movement & & \\
\hline & Standing & 8 & - \\
\hline & March & 2 & - \\
\hline \multirow[t]{3}{*}{3} & Morning review and raising the national flag & & \\
\hline & Standing at attention & 8 & \pm 1 \\
\hline & Standing at ease & 2 & \pm 1 \\
\hline \multirow[t]{3}{*}{4} & Movement for classes & & \\
\hline & March & 2 & - \\
\hline & Standing & 8 & - \\
\hline \multirow[t]{5}{*}{5} & Personal hygiene, line-up and movement for lunch & & \\
\hline & March & 2 & - \\
\hline & Standing at attention & 3 & \pm 1 \\
\hline & Standing at ease & 2 & \pm 1 \\
\hline & March & 3 & - \\
\hline \multirow[t]{5}{*}{6} & Lunch & & \\
\hline & Personal hygiene & 2 & - \\
\hline & Eating & 18 & \pm 1 \\
\hline & Standing & 18 & \pm 1 \\
\hline & March & 2 & - \\
\hline \multirow[t]{4}{*}{7} & Private time and movement for classes & & \\
\hline & Personal hygiene & 4 & $+3-4$ \\
\hline & Standing & 4 & $+5-3$ \\
\hline & March & 2 & \pm 1 \\
\hline \multirow[t]{2}{*}{8} & Cleaning guns and equipment & & \\
\hline & Cleaning guns and equipment & 40 & - \\
\hline \multirow[t]{2}{*}{9} & Movement for classes & & \\
\hline & March & 5 & - \\
\hline \multirow[t]{4}{*}{10} & Lowering the national flag & & \\
\hline & Standing at attention & 4 & \pm 1 \\
\hline & Standing at ease & 4 & \pm 1 \\
\hline & March (slow) & 2 & - \\
\hline
\end{tabular}

\section{Physical activity ratio of the single activities}

A big number of researchers consider, that the energy costs for a single activity during a time unit both for men and for women can be assumed as equal, because of the high level of correlation $(p=0,97)$. 
Based on this analysis and on the recommendations of FAO (FAO 2001), in Table 2 are generalized the separate physical activity ratios for the single activities during the 24-hours period of the Cadets at Vasil Levski National Military University. If several values of a single physical activity ratio (PAR) are available, than the choice is made according to the specificity of the sort of activity and to climatic conditions under which the energy requirement was determined.

Table 2: Generalized standards of the physical activity for the actions of the Cadets at Vasil Levski National Military University

\begin{tabular}{|c|c|}
\hline Activities & PAR \\
\hline \multicolumn{2}{|l|}{ Military training } \\
\hline Physical training & 3,43 \\
\hline $\begin{array}{l}\text { Physical training - Mixed sports } \\
\text { indoors including rest pauses }\end{array}$ & 2,17 \\
\hline $\begin{array}{l}\text { Physical training - Mixed sports } \\
\text { outdoors including rest pauses }\end{array}$ & 3,21 \\
\hline Physical training - Mass games & 5,06 \\
\hline Marching $(4 \mathrm{~km} / \mathrm{h})$ with a $27 \mathrm{~kg}$ load & 4,44 \\
\hline Bayonet exercise & 3,18 \\
\hline Drill without arms & 2,01 \\
\hline Squad and platoon drill & 3,07 \\
\hline Company drill & 3,13 \\
\hline Standing at attention & 1,25 \\
\hline Standing at ease & 1,16 \\
\hline Parade & 4,26 \\
\hline March (slow) & 3,18 \\
\hline March (fast) & 4,69 \\
\hline Tactical exercises & 7,0 \\
\hline Tactical training & 5,22 \\
\hline Field exercises & 4,58 \\
\hline Rifle exercises, lying down & 3,37 \\
\hline Rifle exercises, kneeling & 2,7 \\
\hline Rifle exercises, standing & 3,21 \\
\hline Cleaning guns and equipment & 2,3 \\
\hline Throwing hand grenade & 2,37 \\
\hline Digging trenches & 4,61 \\
\hline $\begin{array}{l}\text { Digging foxhole (mixed with } \\
\text { marching and short rest periods) }\end{array}$ & 4,48 \\
\hline $\begin{array}{l}\text { Obstacle course without pack and } \\
\text { rifle }\end{array}$ & 4,94 \\
\hline Obstacle course with pack and rifle & 6,43 \\
\hline $\begin{array}{l}\text { Creeping and crawling with full } \\
\text { equipment }\end{array}$ & 7,69 \\
\hline Driving a tank & 2,03 \\
\hline Carrying boxes of ammunition & 5,32 \\
\hline
\end{tabular}

\begin{tabular}{|l|l|}
\hline Activities & PAR \\
\hline Guard and sentry drill & 2,44 \\
\hline Sentry duty & 3,13 \\
\hline Fatigue-duty & 3,29 \\
\hline Learning activity & 1,63 \\
\hline Listening to lecture & 1,30 \\
\hline Seminar classes & 1,38 \\
\hline Self-study & 3,18 \\
\hline Moving between classes & 1,23 \\
\hline Break between classes (standing) & \\
\hline Official duties and personal activities & 1,0 \\
\hline Sleeping & 1,07 \\
\hline Lying & 1,16 \\
\hline Sitting quietly & 1,23 \\
\hline Standing & 1,64 \\
\hline Watching TV & 1,8 \\
\hline Working on computer & 1,57 \\
\hline Listening to music & 1,5 \\
\hline Playing cards/board games & 1,22 \\
\hline Reading & 2,4 \\
\hline Dressing and undressing & 2,3 \\
\hline Washing hands/ face and hair & 1,38 \\
\hline Self-study & 1,6 \\
\hline Eating and drinking & 2,1 \\
\hline Walking slowly & 2,0 \\
\hline Driving a car & 1,2 \\
\hline Sitting on a car / bus / train & 4,6 \\
\hline Shopping & 2,8 \\
\hline Housework & 3,4 \\
\hline Bed making & 2,3 \\
\hline Sweeping floor & 1,7 \\
\hline Ironing equipment & 3,6 \\
\hline Cleaning/sweeping yard & 1,4 \\
\hline Writing & \\
\hline
\end{tabular}

\section{Analysis of the duration of the sporting-mass work and determination of the standard for the physical activity for each variant of physical exercises}

The sporting-mass work at Vasil Levski National Military University is carried out according to the time distribution and to the approved by the Head of the Department "Language tuition and physical training" schedule. All cadets perform mass sporting work on Monday and on Wednesday, except the cases, when they have got planned school hours at the same time, which different variants of physical activity.

The sporting-mass work at Vasil Levski National Military University comprise five variants of physical training. The analysis of the typical property of the variants of physical exercises in the sporting-mass work, the specificity of the sort of physical activity and the generalized data for the different activities of the Cadets grant us the basis to recommend the following physical activities:

- Variant I: exercising 1000 m cross and a cross-fit complex - 2.17; 
- Variant II: Sporting games - 5,06;

- Variant III: a general control exercise at a uniform track with hurdles and performance of chin up at horizontal bar, contraction and tension of hands at stronghold on parallel bars - 3,21;

- Variant IV: a special control exercise on a track with hurdles and cross $3000 \mathrm{~m}$ training - 3,43;

- Variant V: exercising a speeded movement within the subdivision without a weapon - 4,44.

\section{Analysis of the obtained results}

During the research of the daily energy requirement of the Cadets it was evaluated the energy requirement of medical healthy cadets form Vasil Levski National Military University - region Veliko Tarnovo, who performed the usual actions from the time schedule. Generally 295 examinations of 59 Cadets during the period 15.05.2017 - до 19.05.2017 were performed. All the examined persons are within the range 19-24 years old and are students from first up to fifth course. The main characteristics of the examined group are listed in Table 3.

Table 3: Characteristics of the examined group

\begin{tabular}{|c|c|c|c|c|}
\hline & & \multicolumn{3}{|c|}{ Cadets $(\mathrm{n}=295)$} \\
\hline Parameter & mark & $\begin{array}{c}\text { Average } \\
\text { value }\end{array}$ & $\begin{array}{c}\text { Standard } \\
\text { deviation }\end{array}$ & Range \\
\hline Age & years & 21 & \pm 1 & $19-24$ \\
\hline Weight & $\mathrm{kg}$ & 72,1 & $\pm 13,6$ & $47,0-108,3$ \\
\hline Височина & $\mathrm{cm}$ & 174,7 & $\pm 10,1$ & $150-196$ \\
\hline $\begin{array}{c}\text { expense of } \\
\text { energy }\end{array}$ & $\mathrm{kcal} /$ day & 2673,6 & $\pm 518,3$ & $1651-4161$ \\
\hline $\begin{array}{c}\text { physical activity } \\
\text { ratio }\end{array}$ & & 1,56 & $\pm 0,13$ & $1,32-2,13$ \\
\hline
\end{tabular}

After a preliminary preparation the Cadet, participating in the Program, performed an individual recording of his physical activity during a 5-days period of his usual daily practice. All sorts of loads, connected with the preparation of the Cadets were taken into account, measuring in minutes the duration of each of them during the day. Based on the results of the 5-days period recording of the described sorts of physical and mental activities, was determined the duration of each of them. By means of the indirect calorimetry was determined the energy requirement for a time unit. $(\mathrm{kcal} / \mathrm{min})$. The minute energy requirement at idle state was determined using data of the WHO, based on data about the sex, age and the weight(Terziev, Nichev, 2017f, p.164; Terziev, Nichev, 2017g, pp.915-919; Terziev, Nichev, Bogdanov, 2017h, pp. 469-475; Terziev, Nichev, Bogdanov, 2017i, pp.671-677; Nichev, 2017j, str. 121-128; Nichev, 2017k, pp. 129-135; Kanev, Terziev, 2017l, pp.413-423; Kanev, Terziev. 2017m, pp. 595-606; Sotirov, Terziev, 2015a, str. 197-207; Sotirov, Terziev, 2015b, p.25; Terziev, 2017n, pp. 893-908; Terziev, 2016a, s.84-90; Terziev. 2017o, p.252; Terziev, 2017p, pp.22-28; Terziev, Vezieva, Arabska, 2016b, str.106-121; Terziev, Manolov, 2016c, pp.1520; Terziev, Minev, Sotirov, Ivanov, 2016d; Terziev. Kanev, 2017q, pp.733-742; Terziev, Madanski, 2017v, pp.917-937; Terziev, Madanski, 2017r, pp.28-36; Terziev, Madanski, 2017s, pp.610-625; Terziev, Madanski, Kanev, 2017t, pp.575-594; Terziev, Madanski, Kanev, 2017u, pp.396-415; Terziev, Madanski, Kanev, 2017v, pp.1331-1346; Terziev, Madanski, Kanev, 2017w, pp.1355-1372; Terziev, Madanski, Kanev, 2017x, pp.1380-1393; Terziev, Nichev, 2016e, pp.101-106; Terziev, Nichev, 2017y, pp.661-666; Banabakova, Georgiev, 2018a, pp. 46-51; Banabakova, Georgiev, 2018b, pp. 462-467; Terziev, Manolov, 2016f, pp.307318; Terziev, Manolov, 2016g, pp.15-29; Terziev, Manolov, 2016h, s.96-106; Terziev, Manolov, 2016i, pp.570-575; Terziev, Manolov, 2016j, pp.9-13).

\section{CONCLUSION}

The knowledge of the real energy requirements of the Cadets form Vasil Levski National Military University contributes to the determination of the most appropriate combination of nutrition products and daily menus for the maintenance of their health and for the insurance of an optimal daily activity. It can also be helpful to the Command of the Military University for the elaboration of new nutrition standards, regulations and rations, which would correspond to the nutrition needs and physiological nutrition standards. The energy requirements in a particular situation grant an appropriate scientific basis for the optimization of the expenditures on food for the physically active Cadets. 
IJASOS- International E-Journal of Advances in Social Sciences, Vol. IV, Issue 12, December 2018

\section{REFERENCE LIST}

Nichev, N., (2017a). Research on the Preparation and Professional Realization of Newly Appointed Logistics Officers. // The 23rd International conference Knowledge-Based Organization, Volume XXIII No 2, Nicolae Balcescu Land Forces Academy, Sibiu, Romania, 2017, pp. 399-404.

Terziev, V., Nichev, N. (2017b). Analysis of the Environment for Military Educational System Functioning and Its Impact on the Preparation of Cadets for Military Professional Activities in the Republic of Bulgaria. // Proceedings of 4th International Conference on Education, Social Sciences and Humanities, 10-12 July 2017, OCERINT, Dubai, UAE, pp. 627-630, ISBN: 978-605-82433-1-6.

Terziev, V., Nichev, N. (2017c). Research on the Management Skills and Abilities Acquired in the Military Education System. // Central Bohemia University International Conference Proceedings 2017, Innovations in Science and Education, March 22-24, Published by Central Bohemia University, 2017, pp. 846-850, ISSN 1805-997X (Print), ISSN 1805-9961 (Online).

Terziev, V., Nichev, N. (2017d). Some Aspects on Forming Preparedness of Logistics Military Officers for Management Activities. // Proceedings of $4^{\text {th }}$ International Conference on Education, Social Sciences and Humanities, 10-12 July 2017, OCERINT, Dubai, UAE, pp. 631-635, ISBN: 978-605-82433-1-6.

Terziev, V., Nichev, N. (2017e). Streamlining Management Solutions for Economic, Effective and Efficient Spending of Resources for Security and Defense. Proceedings of $4^{\text {th }}$ International Conference on Education, Social Sciences and Humanities, 10-12 July 2017, OCERINT, Dubai, UAE, pp. 667-671, ISBN: 978-605-82433-1-6.

Human energy requirements. (2001a). Report of a Joint FAO/WHO/UNU Expert Consultation. Rome, 17-24 October 2001.

Mario Vaz, Nadine Karaolis, Alizon Draper and Prakash Shetty. (2005a). A compilation of energy costs of physical activities. Public Health Nutrition: 8(7A), 2005, pp: 1153-1183, Downloaded from https:/www.cambridge.org/core. IP address: 194.141.64.2, on 22 apr 2017.

Terziev, V., Nichev, N. (2017f). Developing the readiness for the organizational activity of the cadets. // CBU International Conference Book of Abstracts, March 22-24, 2017, Prague, Czech Republic, Innovations in Science and Education, ISBN 978-80-88042-09-9, p.164.

Terziev, V., Nichev, N. (2017g)/ Developing the readiness for the organizational activity of the cadets. // CBU International Conference Proceedings 2017, March 22-24, Prague, Czech Republic, Innovations in Science and Education, 2017, SSN 1805-997X (Print), ISBN 978-80-88042-07-5 (Print edition), pp.915-919.

Terziev, V., Nichev, N., Bogdanov, P. (2017h). Comparative analysis of the formation of military professional skills in the cadets to be trained in logistics specializations. // IJAEDU- International E-Journal of Advances in Education, International Organization Center of Academic Research, www.ocerint.org, 3, 2017, N 9, pp. 469-475, (INT) e-ISSN: 2411-18.

Terziev, V., Nichev, N., Bogdanov, P. (2017i). Comparative analysis of the formation of military professional skills in the cadets to be trained in logistics specializations. // Proceedings of ADVED 2017-3rd International Conference on Advances in Education and Social Sciences 9-11 October 2017- Istanbul, Turkey, 2017, ISBN: 978-605-82433-0-9, pp.671-677.

Nichev, N. (2017j). Ofsetna politika na stranite ot Evropeyskiya Sayuz. Spisanie za nauka „Novo znanie”, Akademichno izdatelstvo „Talant“, Visshe uchilishte po agrobiznes i razvitie na regionite, Plovdiv, Vol 6, No 1, 2017, str. 121-128, ISSN 2367-4598 (Online), ISSN 1314-5703 (Print) (Ничев, Н. Офрсетна политика на страните от Европейския Съюз. Списание за наука „Ново знание”, Академично издателство „Талант“, Висше училище по агробизнес и развитие на регионите, Пловдив, Vol 6 , No 1, 2017, стр. 121-128, (Online) ISSN 2367-4598, (Print) ISSN 1314-5703).

Nichev, N. (2017k). Perspektivi za izpolzvane na ofsetnite sdelki. Spisanie za nauka „Novo znanie”, Akademichno izdatelstvo „Talant“, Visshe uchilishte po agrobiznes i razvitie na regionite - Plovdiv, Vol 6, No 1, 2017, pp. 129-135, (Online) ISSN 2367-4598, (Print) ISSN 1314-5703 (Ничев, Н. Перспективи за използване на офсетните сделки. Списание за наука „Ново знание”, Академично издателство „Талант“, Висше училище по агробизнес и развитие на регионите Пловдив, Vol 6, No 1, 2017, pp. 129-135, (Online) ISSN 2367-4598, (Print) ISSN 1314-5703).

Kanev, D.,Terziev. V. (2017I). Behavioral economics: development, condition and perspectives. // IJASOSInternational E-Journal of Advances in Social Sciences, Vol. III, Issue 8, pp.413-423, e-ISSN: 2411- 
IJASOS- International E-Journal of Advances in Social Sciences, Vol. IV, Issue 12, December 2018

$183 X$.

Kanev, D.,Terziev. V. (2017m). Behavioral economics: development, condition and perspectives. // Proceedings of SOCIOINT 2017- $4^{\text {th }}$ International Conference on Education, Social Sciences and Humanities 10-12 July 2017- Dubai, UAE, pp. 595-606, ISBN: 978-605-82433-1-6.

Sotirov, B., Terziev, V. (2015a). Predizvikatelstva i perspektivi pred obuchenieto po tehnologichni distsiplini. // Parva mezhdunarodna nauchna konferentsiya „Predizvikatelstva pred savremennite organizatsii, svarzani s postigane na ustoychivost - znanie i inovatsii v upravlenieto i funktsioniraneto",Plovdiv. ISBN 978-619-7246-04-9 (DVD), ISBN 978-619-7246-06-3 (e-book), str. 197-207, Сотиров, Б., Терзиев, В. Предизвикателства и перспективи пред обучението по технологични дисциплини. // Първа международна научна конференция „Предизвикателства пред съвременните организации, свързани с постигане на устойчивост - знание и иновации в управлението и функционирането“, 12 декември 2015 г., Пловдив, 2015, ISBN 978-619-7246-04-9 (DVD), ISBN 978-619-7246-06-3 (e-book), стр.197-207.

Sotirov, B., Terziev, V. (2015b). Challenges and perspectives to the training in technological subjects. // Book of Abstracts: First International Scientific Conference „Sustainability Challenges in Modern Organizations - Knowledge \& Innovation in Management \& Operation”, p.25, ISBN 978-619-7246-03-2 (DVD), ISBN 978-619-7246-05-6 (e-book).

Terziev, Venelin. (2017n). National security of the republic of Bulgaria. // The Chinese Journal of International Politics, 10, 2017, N 4 (2), pp. 893-908, ISSN 1750-8916, Source Normalized Impact per Paper (SNIP): 1.901 SCImago Journal Rank (SJR): 1.238 Impact factor: 1.594 5-Yr impact factor: 1.747.

Terziev. V. (2016a). Human resource management systems in security and defense: social policies for social activities. // XXXII Mezhdunarodnaya nauchno-prakticheskaya konferentsiya, Evraziyskiy soyuz uchenayh (ESU), Ezhemesyachnayy nauchnayy zhurnal № 12 (33)/ 2016 Chasty 1, Moskva 30.12.2016g., s.84-90, ISSN 2411-6467 (Terziev, Venelin. Human resource management systems in security and defense: social policies for social activities. // XXXII Международная научнопрактическая конференция, Евразийский союз ученых (ЕСУ), Ежемесячный научный журнал № 12 (33)/ 2016 Часть 1, Москва 30.12.2016г., 2016, с.84-90, ISSN 2411-6467).

Terziev. V. (20170). Entry Opportunities in the Bulgarian Military - Educational System and Ensuring of Civil Rights. // 3rd Central and Eastern European LUMEN International Scientific Conference New Approaches in Social and Humanistic Sciences 8-10 June 2017, Chisinau, Republic of Moldova, 2017, ISBN: 978-973-166-461-3, p.252.

Terziev. Venelin. (2017p). National security of the republic of Bulgaria. // International Journal of Management and Applied Science, 3, 2017, N 4, ISSN: 2394-7926, pp.22-28.

Terziev, V., Vezieva, D., Arabska, E. (2016b). Balgarskite universiteti i vazmozhnostite na Operativna programa „Nauka i obrazovanie za inteligenten rastezh". // Mezhdunarodna nauchna konferentsiya "Obrazovanie, nauka, ikonomika i tehnologii“ 23-24 yuni $2016 \mathrm{~g}$. Akademichno spisanie „Upravlenie i obrazovanie“", 12, 2016, N 1, ISSN 1312-6121, str.106-121 (Терзиев, В., Везиева, Д., Арабска, Е. Българските университети и възможностите на Оперативна програма „Наука и образование за интелигентен растеж". // Международна научна конференция „Образование, наука, икономика и технологии“ 23-24 юни 2016 г. Академично списание „Управление и образование“, 12, 2016, N 1, ISSN 1312-6121, стр.106-121).

Terziev, V., Manolov, D. (2016c). Creation of good organizational environment for scientific research activity (Създаване на добра организационна среда за научноизследователска дейност) // Актуальные проблемы глобализации, Салоники, Греция (Actual problems of globalization, August 29, 2016, Thessaloniki, Greece), Scientific journal Economics and Finance, Actual problems of globalization Collection of scientific articles, 2016, ISBN 978-617-7214-34-1, pp.15-20.

Terziev, V., Minev, R., Sotirov, B., Ivanov, K. (2016d). Vazmozhnosti za izgrazhdane na tsentar za kompetentnost $v$ Severen tsentralen rayon na Republika Balgariya. // Godishna universitetska nauchna konferentsiya, 20-21 oktomvri 2016 g. NVU „Vasil Levski“- Veliko Tarnovo. Sbornik dokladi tom 2, Nauchni napravleniya „Prirodomatematicheski nauki” i „Tehnicheski nauki”, ISSN 1314-1937.

Terziev. V., Kanev, D. (2017q). Education and Behavioural Failures. // Proceedings of ADVED 2017- 3rd International Conference on Advances in Education and Social Sciences 9-11 October 2017- Istanbul, Turkey, pp.733-742, ISBN: 978-605-82433-0-9. 
IJASOS- International E-Journal of Advances in Social Sciences, Vol. IV, Issue 12, December 2018

Terziev, V, Madanski, V. (2017v). Development of military education system in Bulgaria. // American Journal of Education, The University of Chicago Press, 2017, 123, 2017, N 4 (2), ISSN: 0195-6744, pp.917937.

Terziev, V, Madanski, V. (2017r). Guidelines for development of military education system in Bulgaria (Nasoki za razvitie na voennoobrazovatelnata sistema na Balgariya). // Topical questions of contemporary science, United States of America 2017, ISBN 978-0-9988732-1-3, pp.28-36.

Terziev, V, Madanski, V. (2017s). Guidelines for development of military education system in Bulgaria. // Proceedings of the VII International Academic Congress „Fundamental and Applied Studies in EU and CIS Countries” (United Kingdom, Cambridge, England, 26-28 February 2017), Cambridge University Press, ISBN: 978-0-875-83597-4, 7, 2017, pp.610-625.

Terziev, V, Madanski, V., Kanev, D. (2017t). Entry opportunities in the bulgarian military-educational system and ensuring of civil rights. // Proceedings of SOCIOINT 2017- $4^{\text {th }}$ International Conference on Education, Social Sciences and Humanities 10-12 July 2017- Dubai, UAE, 2017, ISBN: 978-60582433-1-6, pp.575-594.

Terziev, V, Madanski, V., Kanev, D. (2017u). Entry opportunities in the bulgarian military-educational system and ensuring of civil rights. // IJAEDU- International E-Journal of Advances in Education, 3, 2017, N 8 , e-ISSN:2411-1821, pp.396-415.

Terziev, V, Madanski, V., Kanev, D. (2017v). Entry opportunities in the Bulgarian military-educational system. // Sport, Education and Society, Taylor \& Francis, 22, 2017, N 8(2), Source Normalized Impact per Paper (SNIP): 1.459 SCImago Journal Rank (SJR): 1.005 Impact factor: 1.269 Ranking: 60/230 (Education \& Educational Research), 20/44 (Hospitality, Leisure, Sport and Tourism), 51/82 (Sport Sciences), Print ISSN: 1357-3322, Online ISSN: 1470-1243, pp.1331-1346.

Terziev, V, Madanski, V., Kanev, D. (2017w). Condition and capabilities of the military-educational system of the Republic of Bulgaria. // Sport, Education and Society, Taylor \& Francis, 22, 2017, N 8(2), Source Normalized Impact per Paper (SNIP): 1.459 SCImago Journal Rank (SJR): 1.005 Impact factor: 1.269 Ranking: 60/230 (Education \& Educational Research), 20/44 (Hospitality, Leisure, Sport and Tourism), 51/82 (Sport Sciences), Print ISSN: 1357-3322 Online ISSN: 1470-1243, pp.1355-1372.

Terziev, V, Madanski, V., Kanev, D. (2017x). Directions for improvement of the military-educational system and its contribution for strengthening national security and the defence of the country. // Sport, Education and Society, Taylor \& Francis, 22, 2017, N 8(2), Source Normalized Impact per Paper (SNIP): 1.459 SCImago Journal Rank (SJR): 1.005 Impact factor: 1.269 Ranking: 60/230 (Education \& Educational Research), 20/44 (Hospitality, Leisure, Sport and Tourism), 51/82 (Sport Sciences), Print ISSN: 1357-3322 Online ISSN: 1470-1243, pp.1380-1393.

Terziev, V., N.Nichev. (2016е). Икономически характеристики на офсетните сделки с отбранителни продукти (Economic characteristics of offset transactions with defense products). // Scientific journal „Economics and Finance“, Problems of development modern science: Theory and practice Collection of scienfic articles, 2016, ISBN 978-617-7214-33-4, pp.101-106.

Terziev. V., N.Nichev. (2017y). Main features of the offsets in defense trade. Proceedings of SOCIOINT 2017- 4th International Conference on Education, Social Sciences and Humanities 10-12 July 2017Dubai, UAE, 2017, ISBN: 978-605-82433-1-6, pp.661-666.

Banabakova, V., Georgiev, M. (2018a). Military professional forming of the cadets at Vasil Levski National Military University. // IJAEDU- International E-Journal of Advances in Education, April 2018, Turkey, International Organization Center of Academic Research, www.ocerints.org, Istanbul, Turkey, 2018, pp. 46-51, 4, 2018, N 10, e-ISSN: 2411-1821.

Banabakova, V., Georgiev, M. (2018b). Military professional forming of the cadets at Vasil Levski National Military University. // Proceedings of INTCESS2018- 5th International Conference on Education and Social Sciences 5-7 February 2018- Istanbul, Turkey, International Organization Center of Academic Research, www.ocerints.org, Istanbul, Turkey, 2018, pp. 462-467, ISBN: 978-605-82433-2-3.

Terziev, V., Manolov, D. (2016f). Методика за планиране на снабдяването с вещево имущество в ресурсно ограничена среда (Methodology for planning of supply with clothes, shoes and equipment in Bulgarian armed forces). // Tenth International Scientific Conference The power of knowledge, 7-9 October 2016, Agia Triada, Republic of Greece, Knowledge International Journal Scientific papers, Institute of Knowledge Management, Skopje, 14, 2016, N 1, ISSN 1857-92, pp.307-318. 
IJASOS- International E-Journal of Advances in Social Sciences, Vol. IV, Issue 12, December 2018

Terziev, V., Manolov, D. (2016g). Изграждане на капацитет в публичните служби за заетост (Capacity building in public employment services). // Scientific journal „Economics and Finance“, Problems of development modern science: Theory and practice - Collection of scienfic articles, 2016, ISBN 978617-7214-33-4, pp.15-29.

Terziev, V., Manolov, D. (2016h). Particular features of carrying out a procurement procedure at the Ministry of Defense. // XIII Mezhdunarodnaya nauchno-prakticheskaya konferentsiya „Sotsialynoekonomicheskie nauki i gumanitarnaye issledovaniya", g. Novosibirsk, 28 lyunya, 25 lyulya 2016 g., ISBN 978-5-00068-616-4, s.96-106, Terziev, V., Manolov, D. Particular features of carrying out a procurement procedure at the Ministry of Defense. // XIII Международная научно-практическая конференция „Социально-экономические науки и гуманитарные исследования”, г. Новосибирск, 28 Июня, 25 Июля 2016 г., ISBN 978-5-00068-616-4, с.96-106.

Terziev, V., Manolov, D. (2016i). Систематизация на първична информация в статистически редове в планирането на снабдяването с вещево имущество в Българската армия (Systematization of original information in statistical rows in the planning of supply with clothes and equipment in Bulgarian armed forces). // Tenth International Scientific Conference The power of knowledge , 7-9 October 2016, Agia Triada, Republic of Greece, Knowledge International Journal Scientific papers, Institute of Knowledge Management, Skopje, 14, 2016, N 2, ISSN 1857-92, pp.570-575.

Terziev, V., Manolov. D. (2016j). Analysis of NATO logistics handbook. // Scientific journal „Economics and finance“, Verlag SWG imex GmbH, Nurnberg, Deutshland, Trends in der Entwicklung der nationalen und internationalen Wissenschaft, 2016, ISBN 978-617-7214-44-0, pp.9-13. 